초고령 사회, 한국에서 노인신경학의 중요성

석승한

원광대학교 의과대학 산본병원 신경과

\title{
The importance of geriatric neurology in Korea becoming a super-aged society
}

\section{Seung-Han Suk}

Department of Neurology, Wonkwang University Sanbon Medical Center, Wonkwang University Shcool of Medicine, Gunpo, Korea

Received: January 10, 2022

Accepted: January 18, 2022

Corresponding author:

Seung-Han Suk, MD, PhD

Department of Neurology,

Wonkwang University Sanbon

Medical Center, Wonkwang

University Shcool of Medicine,

321 Sanbon-ro, Gunpo 15865,

Korea

Tel: +82-31-390-2231

Fax: +82-31-390-2244

E-mail : suksh@wonkwang.ac.kr
Korea is rapidly aging unprecedentedly and had the second-highest life expectancy in the world in 2020. It is expected to become the longest-lived country by 2030. With the aging population around the world, the prevalence of major neurological diseases such as dementia, stroke and Parkinson disease has been increasing. At the same time, medical expenses for the elderly caused by these diseases are constantly increasing. In a 2016 Global Burden of Disease study, neurological diseases are recognized as a major cause of death and disability and the burden of disease is very high. Therefore, the importance of establishing effective prevention and proper treatment strategies for neurological diseases and setting up rehabilitation program and social support system has been growing in the aged society. It is a major task in the healthcare field to be solved as soon as possible. At a time when the population composition in Korea is changing in a super-aged society, there is a growing demand for the importance of geriatric neurology and the role of neurologist as a expert on geriatric medicine. In addition, its importance is increasing to play a role of neurologists in the area of community care and palliative care for neurological diseases established as a national healthcare agenda. Therefore, continuous education on general geriatrics and on geriatric neurology are essential components in the neurology training program, and are necessary to improve and expand expertise in diagnosing and treating acute and chronic neurological diseases in the elderly.

Keywords: Aging; Geriatrics; Neurology; Dementia; Stroke

\section{서론}

우리나라는 세계에서 유래 없이 빠르게 고령화되고 있어 2020년 기대수명이 세계에서 두 번째로 높았고, 2030년에는 최장수국이 될 것으로 예측하고 있다[1]. 이러한 고령화 추세는 세계적인 현상 으로 실버쓰나미(silver tsunami) 또는 그레이쓰나미(grey tsuna$\mathrm{mi}$ 로 표현되고 있다[2]. 고령화와 더불어 뇌졸중, 치매, 파킨슨병 같은 주요 신경계 질환의 유병률이 급격히 높아지고 신경계 질환
에 의한 노인의료비가 지속적으로 늘고 있다. 2016년 Global Burden of Disease (GBD) 연구에서는 신경계 질환이 세계적으로 사망과 장애의 주요 원인으로 질병부담이 매우 높은 것으로 인식 되고 있다[3]. 따라서 고령 사회에서 신경계 질환에 대한 효과적인 예방 및 치료 전략 수립, 재활 및 사회적 지원체계 구축에 대한 중 요성이 높아지고 있으며, 해결해야 할 보건의료 분야의 국가적 주 요 과제이다.

노인신경학은 신경계 질환에 취약한 신경계 노화에 대한 전문 
지식을 이해하고 연구하며 노인에서 흔히 발생하는 급성 및 만성 신경계 질환을 진단과 치료를 통하여 노인 환자를 돌보는 신경과 학의 세부 전문분야이다[4]. 초고령 사회로 인구구성이 급격히 변 화가 있는 현 시점에 노인신경학의 중요성과 노인의료 전문가로 서 신경과 의사의 역할에 대한 요구가 커지고 있다. 따라서 노인 의학에 대한 지속적인 교육과 노인신경학에 대한 관심과 이해를 높이는 것은 신경과 전문의 수련과정에 필수 요소이며, 신경과 의 사로서의 노인에서 급·만성 신경계 질환을 예방하고 진단 및 치료 를 위한 전문성을 높이는 데 반드시 필요하다. 또한 국가적 보건 의료 과제인 커뮤니티 케어 및 신경계 질환의 완화의료 분야에서 신경과 의사의 역할을 수행하기 위하여 노인신경학에 대한 중요 성이 커지고 있다.

\section{나이 들어가는 대한민국}

2020년 통계청 생명표에 따르면 우리나라의 기대수명은 전체 83.5세, 남자 80.5세, 여자는 86.5세로 우리나라 남자는 경제협력 개발기구(Organization for Economic Cooperation and Development, OECD) 평균(77.9년)보다 2.6년, 여자는 OECD 평균 (83.2년)보다 3.3년 높았다. 또한 2011년부터 2020년까지 65세 이상 인구의 연평균 증가율은 $4.4 \%$ 로, $\mathrm{OECD}$ 평균(2.6\%)의 약 1.7 배로 $\mathrm{OECD}$ 가운데에서도 가장 빨랐다. 인구구성 측면에서 2020 년 우리나라 65 세 이상 노령인구율은 $15.7 \%$ 였으며, 2030년 에는 $25.5 \%$, 그리고 2040년에는 34.4\%로 추계되었다[5]. 2019 년 국제연합(United Nations, UN)에서 발표한 world population aging 2019 보고서에서는 2019년부터 2050년 사이에 가장 노령 인구가 늘어날 것으로 예상하는 나라는 한국이었으며, 이러한 추 세라면 2030년에 우리나라는 최장수 국가가 될 것이고 한국 여성 의 기대수명이 90 세가 넘을 것으로 전망된다[1]. 더 세심히 살펴
봐야 할 것은 고령인구 구조 변화로 75 세 이상 초고령 노인이 2020 년 전체 인구의 $6.9 \%$ 인 346만 명에서 2030년에 $10.5 \%$ 인 524만 명, 2040년에는 17.8\%인 864만 명으로 예상된다(Figure 1). 우리나라의 이러한 급격한 고령화 추이는 세계적으로 전례가 없이 빠르기 때문에 저출생과 더불어 빠른 시간 내에 고령 사회에 대비하기 위한 새로운 미래 의료 시스템을 준비하는 것은 중요한 국가적 과제이다.

\section{고령 사회에서 신경계 질환}

급격한 고령화에 따른 인구구조의 변화는 보건의료 분야에 많은 변화와 이에 대한 대응을 요구하고 있는데, 특히 노인에서 흔히 발생하는 신경계 질환들은 치명적이거나 장애를 동반하기 때문에 오랜 기간 동안 돌봄이 필요하고, 높은 사회적 기회비용이 요구된 다. $2016 \mathrm{GBD}$ 연구에 따르면 1990년에서 2016년까지 기간에 급격한 고령화 때문에 치매, 뇌졸중 그리고 파킨슨병의 유병률이 2-3배 증가하였고 이 질환들은 노인에서 장애와 사망의 주요 원 인 질환으로 환자와 가족들에게 심각한 신체적, 심리적, 재정적 부담이 되는 것으로 보고하였다[3]. 이러한 현상은 우리나라에서 도 유사하여 2019년 일산공단병원 연구보고서에서 따르면 뇌졸 중, 치매, 파킨슨병 3가지 노인성 질환이 70-79세에 가장 많이 발 생하였으며, 가정과 사회에 큰 부담이 되고 있다고 기술하였다[6]. 따라서 65세 이후에 신경계 질환에 대한 남은 평생 위험도(remaining lifetime risk) 증가와 함께 이 질환들에 대한 예방이 더욱 중요해졌다. 뇌졸중, 치매, 파킨슨병 각각의 발병 시기를 1-3년 늦추기만 하여도, 초고령 노인에서 이러한 신경 질환의 남은 평생 위험도를 $50 \%$ 이상 낮출 수 있어서[7], 국가적, 가정적으로 질병 부담을 낮출 수 있는 효과로 이어질 수 있다.

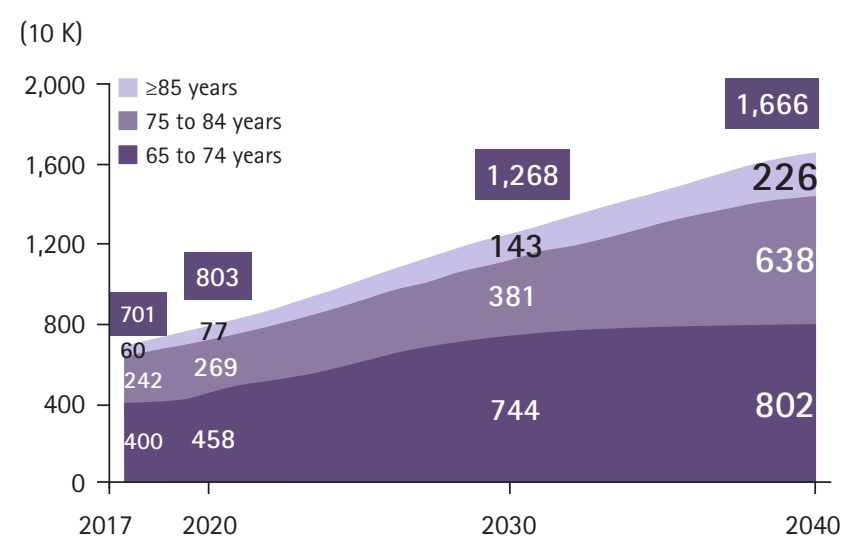

$(\%)$

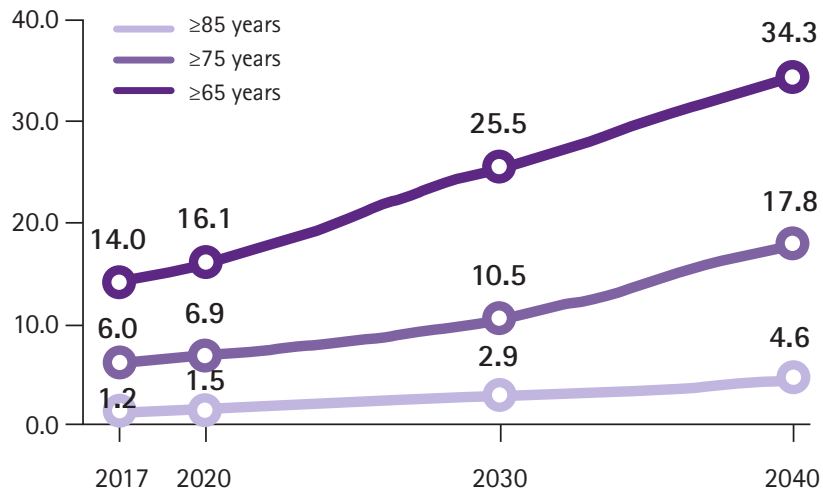

Figure 1. Estimation of the elderly population. Source: 2019 Statistics Korea (https://www.kostat.go.kr/portal/korea/kor_nw/1/1/index. board?bmode=readEtaSeq=385624). 


\section{노화와 신경계 질환}

\section{1. 신경계 노화}

고령과 노화 자체는 질병 상태가 아니다. 그럼에도 신경계 질환을 가진 고령 환자들 진료하기 위해서는 정상적인 신경계 노화에 대 하여 이해하는 것이 매우 중요하다. 개인의 노화 상태에 따라 다 르게 나타날 수 있는 임상적 특성을 이해하는 데 필요하고, 노인 에서 나타나는 다양한 임상 징후, 기저 원인을 찾고 이에 대한 적 절한 치료에 도움이 되기 때문이다.

노화란 나이 들면서 점차적으로 진행되는 생물학적 기능 저하 를 의미하며, 신체의 기능 손실과 더불어 사회적 기능 저하의 주 요 원인이다. 노화의 진행 속도는 개인의 유전적, 환경적 요인에 따른 차이가 있을 수 있기 때문에 생물학적 노화 정도와 실제 연 령에 따른 노화와 일치하는 것은 아니다. 따라서 세계적으로 고 령인구 증가와 함께 치매, 뇌졸중을 포함한 노인성 질환의 유병 률이 높아지면서 노인들이 지속적으로 편안한 삶을 살아갈 수 있 도록 신체적, 정신적 그리고 사회적 기능을 유지하는 과정인 건 강한 노화(healthy aging)에 대한 관심이 높아지고 있다[8]. Figure 2와 같이 신경계 노화는 자연적이고 비가역적 현상으로 분자 수준의 변화, 뇌 세포 및 구조적 변화가 결국에는 뇌 기능 저하와 신경계 질환으로 나타나게 된다[9]. 따라서 신경계 노화의 원인과 과정을 이해하는 것은 신경계 노인성 질환의 병리기전을 밝혀내
기 위해 필요할 뿐만 아니라 질병을 예방하고, 진단 및 치료하는 데 필요하다.

\section{1) 노화의 분자 메커니즘}

분자 수준에서 노화과정은 유전체 불안정성(genome instability), 말단소체(telomere)의 역할, 그리고 후성유전학의 영향에 의한 것 으로 생각하고 있다. 우선 유전체 불안정성은 DNA 손상과 분해, 회복 과정에서 발생한 오류 파국(error catastrophe)에 의한 유전 자 돌연변이 축적의 결과로서 발생할 수 있다. 다음으로 $\mathrm{DNA}$ 와 단백질로 구성된 염색체의 말단 구조인 말단소체는 세포분열 과 정에서 유전 정보 손실을 보호하고 손상을 막는다. 그러나 세포분 열이 반복되면서 말단소체가 짧아져 DNA를 보호할 수 없어지게 되어 결국에는 세포분열이 멈추고 노화와 세포사멸이 일어나게 된다. 따라서 말단소체를 세포 노화의 생물학적 시계(biological clock)라고 한다. 마지막으로 DNA 염기서열의 변화 없이 나타나 는 유전자 기능의 변화가 유전되는 현상을 말하는 후성유전학은 $\mathrm{DNA}$ 메틸화와 탈메틸화, 히스톤 변형에 의한 $\mathrm{DNA}$ 의 구조적 변 형과 염색질의 구조적 변형을 일으키게 된다. 따라서 노화에서 후 성유전학적 현상은 유전적으로 동일한 세포 또는 개체들이 유전 자의 발현을 달리함으로써 표현형의 차이를 가져와서 퇴행성 뇌 질환의 발생과 수명에 영향을 미치게 된다.

\section{SENESCENCE}
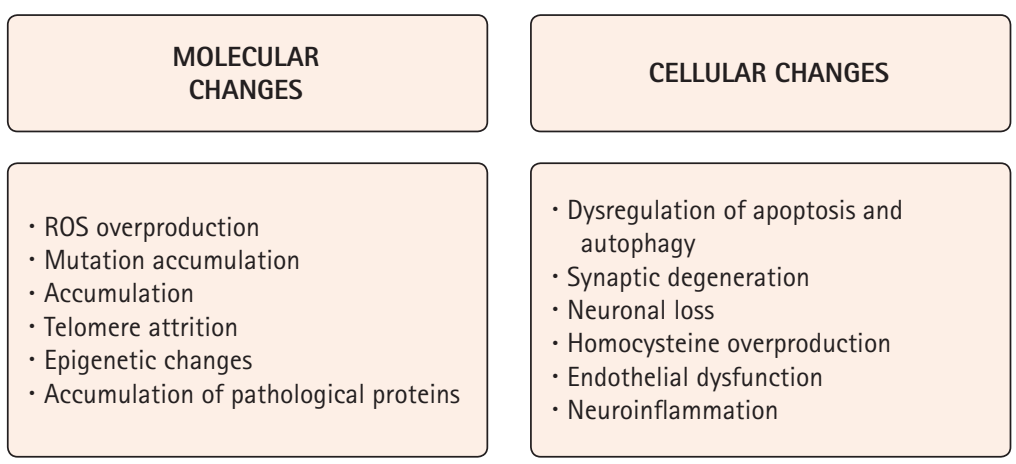

\section{DETERIORATION OF ORGANS OR} FUNCTIONS
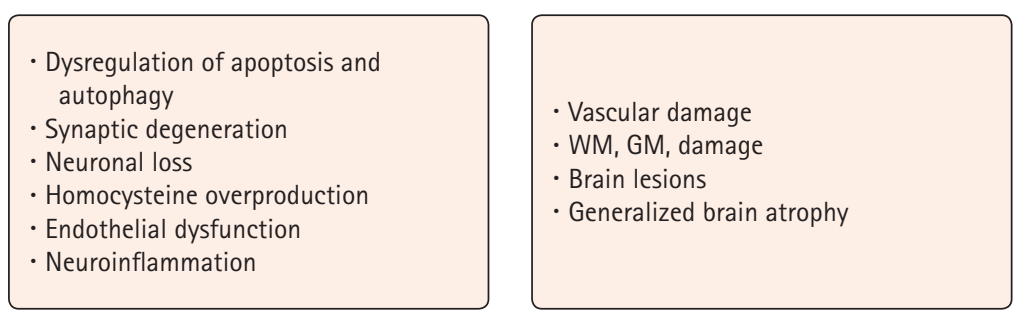

\section{NEUROLOGICAL DISEASES}

$$
\begin{aligned}
& \text { - Stroke } \\
& \text { - Epilepsy } \\
& \text { - Dementia } \\
& \text { - Parkinson's disease } \\
& \text { - Multiple sclerosis } \\
& \text { - Brain tumors }
\end{aligned}
$$

Figure 2. Senescence process and neurologic diseases. Adapted from Kowalska $M$ et al. Aging and neurological diseases. London: IntechOpen; 2017, according to the Creative Commons license [9]. ROS, reactive oxygen species; WM, white matter of the brain; GM, gray matter of the brain. 


\section{2) 뇌 세포 및 구조 변화}

노화에 따른 뇌 세포의 손실과 구조 변화의 정도는 개인마다 차이 가 있다. 노화는 지속적으로 뉴런 소실과 함께 성상교세포(astrocyte), 희소돌기아교세포, 미세아교세포 같은 신경아교세포와 뇌 혈관세포의 소실과 변화가 동반된다. 일반적으로 회백질(gray matter)의 부피는 나이에 따라 직선형 감소(linear decline)를 보여 40세 이후부터 10 년마다 5\%씩 감소하며 전전두엽 부위(prefrontal area)에서 현저하게 관찰된다. 또한 측두엽, 해마에서도 흔히 나타난다. 백질의 감소는 회백질의 감소보다 3 배나 크다. 이러한 노화 관련 해부학적 변화는 신경전달물질의 감소, 뇌혈류 조절기 능 저하, 뇌 대사 조절기능 저하로 이어지게 된다.

\section{2. 노인에서 흔한 신경계 질환들}

\section{1) 치매}

노화에 따른 인지기능 변화에서 결정지능(crystallized intelligence)은 60 대 이후에도 안정적이거나 오히려 향상될 수 있다. 반 면 유동지능(fluid intelligence)은 20대 이후 점차 감소하며 노화 과정에서 현저하게 떨어지고, 노인에서 기억 감퇴, 실행기능 저 하, 새로운 정보 습득능력의 제한으로 나타난다. 인지예비력(cognitive reserve)과 신경형성력(neuroplasticity)에 대한 이론들은 노화에 따른 인지기능 저하나 치매를 예방할 수 있다는 관련 근거 로 생각되고 있다. 2018년 중앙치매센터에서 발행한 국제 치매정 책동향 보고서에 따르면, 한국은 빠른 기대수명 연장과 지속적인 저출생으로 인한 급격한 고령화로 인해 치매 환자수가 2018년에 는 74만 9,000명에서 2025년에는 100만 명, 2050년에는 300만 명이 넘을 것으로 추계하였으며, 특히 80 세 이상에서 초고령 노인 수 증가와 동시에 치매 환자가 급격히 늘 것으로 예측하였다
(Figure 3). 이와 함께 치매 환자 관리비용이 2018년 15.7조에서 2030년에 32조, 2060 에는 100 조가 넘을 것으로 추계하였다 (Figure 4).

\section{2) 뇌졸중}

뇌졸중은 노화와 밀접한 관계가 있어 뇌졸중 환자의 약 $8 \%$ 정도 만이 45 세 미만으로 환자 대부분이 장노년층이며, 50 세 이후 10 년마다 그 발생률이 거의 두 배씩 늘어나는 것으로 알려져 있다 (Figure 5). 2018년 대한뇌졸중학회의 뇌졸중 역학보고서에서 2006년 질병관리본부 보고서 자료를 근거로 추산했을 때 성인 40 명 중 1 명이 뇌졸중 환자이고, 뇌졸중 유병률은 연령대가 높을수 록 높아지는 추세를 보인다(Figure 6). 이러한 경향은 나이가 들수 록 고혈압, 당뇨병, 비만, 심혈관 질환의 유병률이 높아지면서 뇌 혈관에 미치는 영향이 커지는 것과 관련이 있다.

\section{3) 파킨슨병}

파킨슨병도 노화와 밀접한 관련이 있는 퇴행성 질환으로 유병률 이 60 대 이후에 급격히 늘어난다. 10년간 전국 유병률 조사[10]에 의하면, 인구 10 만 명당 전체 파킨슨병의 유병률을 보면 2004년 에는 10 만 명당 41.4명, 2013년도에는 142.5명으로 10년 동안 유병률은 해마다 약 $13.2 \%$ 씩 증가하였다. 연령대별 유병률은 2011년 이전에는 70대가 최대 유병률을 보였으나, 2011년부터 2013년까지는 80대 이상이 최대 유병률을 보였다(Figure 7) [10].

\section{4) 뇌전증}

노인에서 뇌전증은 뇌혈관 질환과 신경계 퇴행성 질환이 가장 흔 한 원인으로 알츠하이머병 환자, 독성 및 대사성 뇌증, 뇌손상이

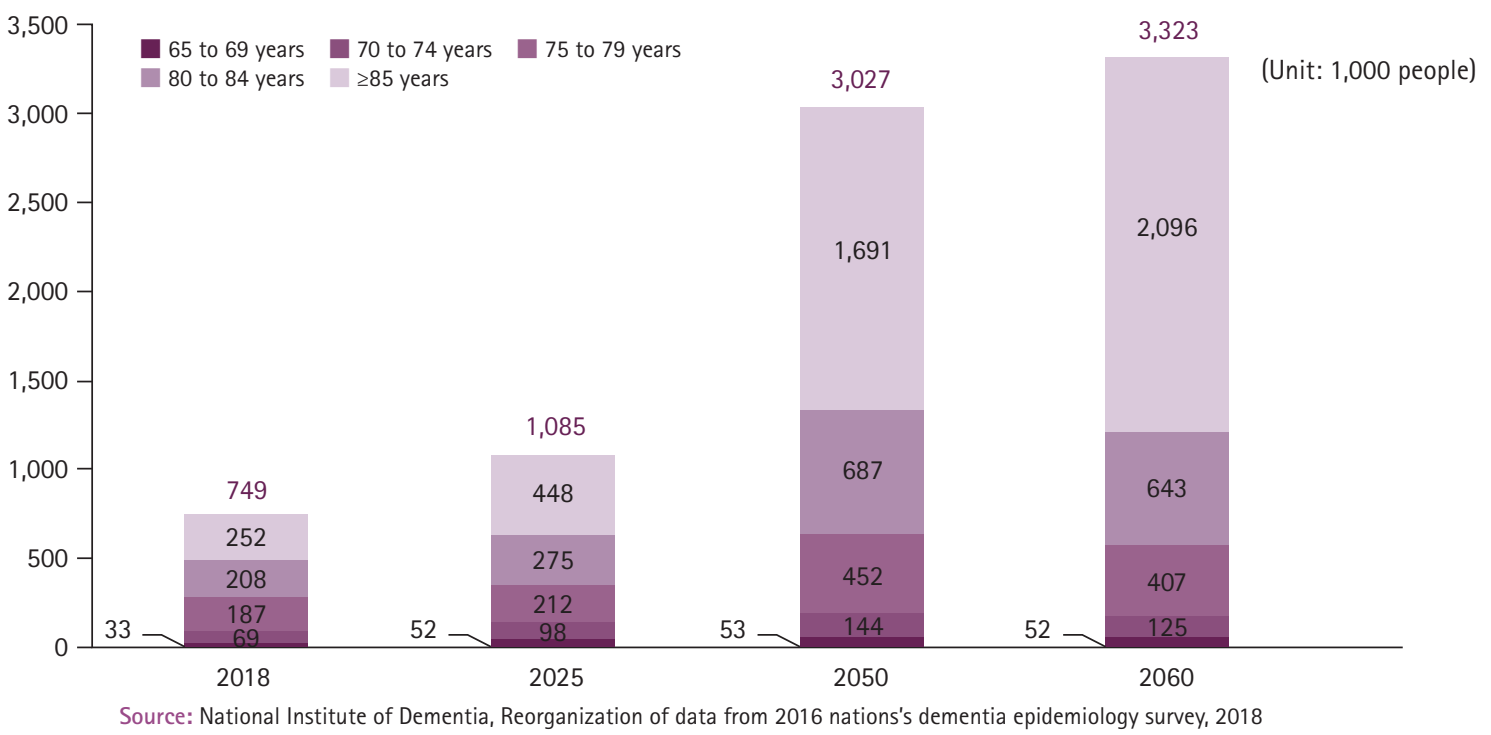

Figure 3. Prediction of the trend of increasing number of dementia patients by age in Korea. Source: National Institute of Dementia, Global trends of dementia policy 2018 (https://www.nid.or.kr/info/dataroom_view.aspx?bid=185). 


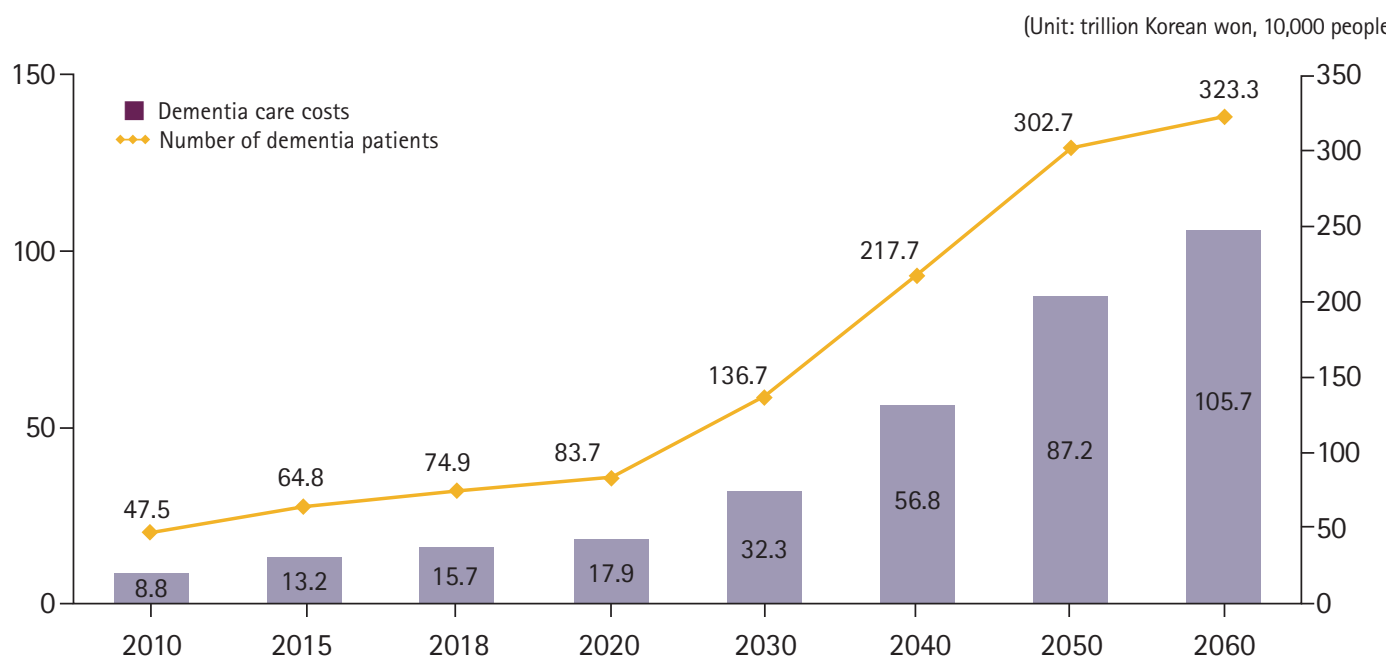

Source: National Institute of Dementia, Reorganization of data from 2016 nations's dementia epidemiology survey, 2018

Figure 4. Prediction of the trend of increasing cost for management of dementia patients. Source: National Institute of Dementia, Global trends of dementia policy 2018 (https://www.nid.or.kr/info/dataroom_view.aspx?bid=185).

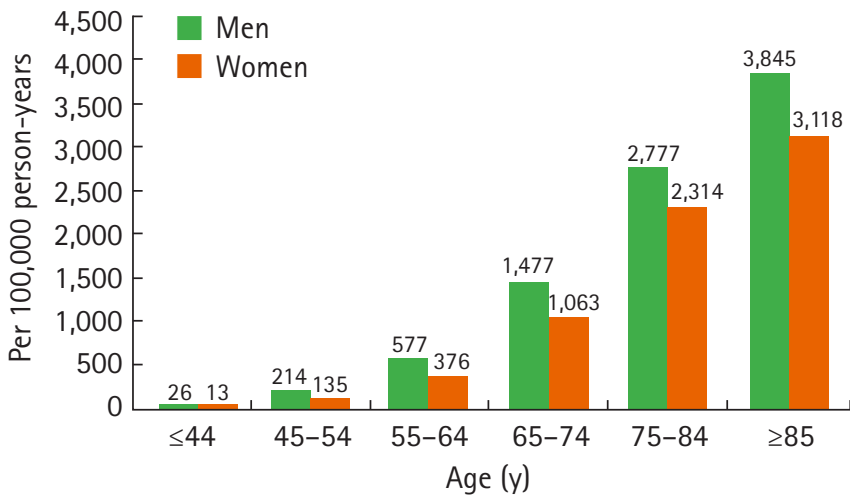

Figure 5. The incidence of stroke according to gender and age. Source: Construction of National Surveillance System for Cardiovascular \& Cerebrovascular Diseases. Korean Center for Disease Control, 2006

있는 노인에서 경련발작의 가능성 높아진다. 대한뇌전증학회의 뇌전증 발생률과 유병률 연구에 의하면[11], 연령별 발병률은 J자 형 곡선을 보여서 30대에 가장 낮았고 이후 증가했으며, 60-94세 사이에 폭발적으로 증가하는 추세를 보였고, 유병률도 비슷한 추 이를 보인다(Figure 8) [11].

\section{3. 고령 환자 치료의 어려움}

신경계 노화와 함께 신체 노화가 진행되면서 외부 자극이나 스트 레스에 대한 신경 반응뿐 아니라 신체 반응 저하도 생기게 된다. 또한 노인 환자에서는 다발성 장기 기능 부전 및 선행 동반질환이 있는 경우가 많아서 여러 가지 약물을 복용하고 있을 가능성이 높 고, 신경계 질환의 전형적인 증상과 다르게 나타날 수 있다. 이러

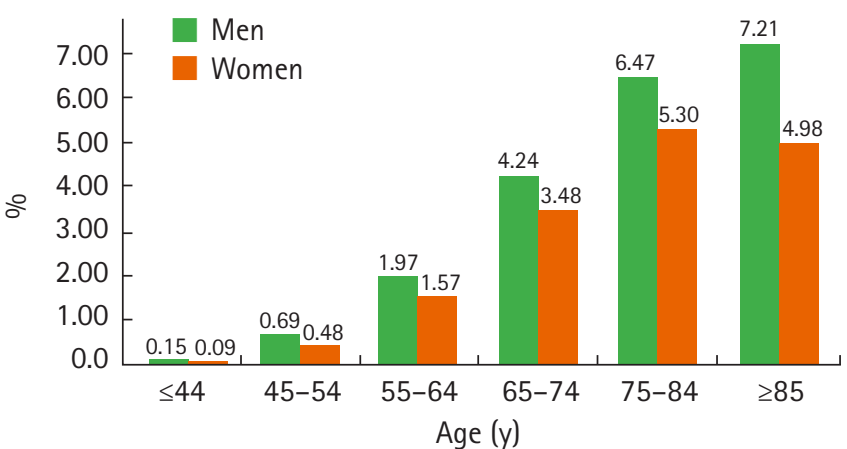

Figure 6. The prevalence of stroke according to gender and age. Source: Construction of National Surveillance System for Cardiovascular \& Cerebrovascular Diseases. Korean Center for Disease Control, 2006.

한 상황은 정확한 진단과 적절한 치료를 늦추게 하거나 치료과정 에서 걸림돌이 될 수 있다. 특히 고령 노인에서 뇌졸중이 발생한 경우 진단과 치료가 늦어지고 합병증 발생 가능성을 매우 높이며, 회복을 어렵고 더디게 하여 심각한 후유장애 발생에 영향을 줄 수 있다. 따라서 노인 뇌졸중 환자는 재활치료에 한계가 있을 수 있 다. 이와 같은 상황들은 결국 고령 환자를 치료하는 과정에서 가 족 및 의사가 적극적이지 않게 하는 주된 원인이 되기도 한다. 이 뿐 아니라 고령 신경계 질환에 대한 임상적 근거 자료가 충분치 못한 것은 적절한 진단과 치료에 제한점이 되고 있다[12]. 그러므 로 노인 신경계 질환 환자의 경우 우선적으로 체계적이고 포괄적 인 사전평가(comprehensive geriatric assessment)가 반드시 필요 하고, 진단과 치료에 세심한 관심과 주의가 필요하다. 


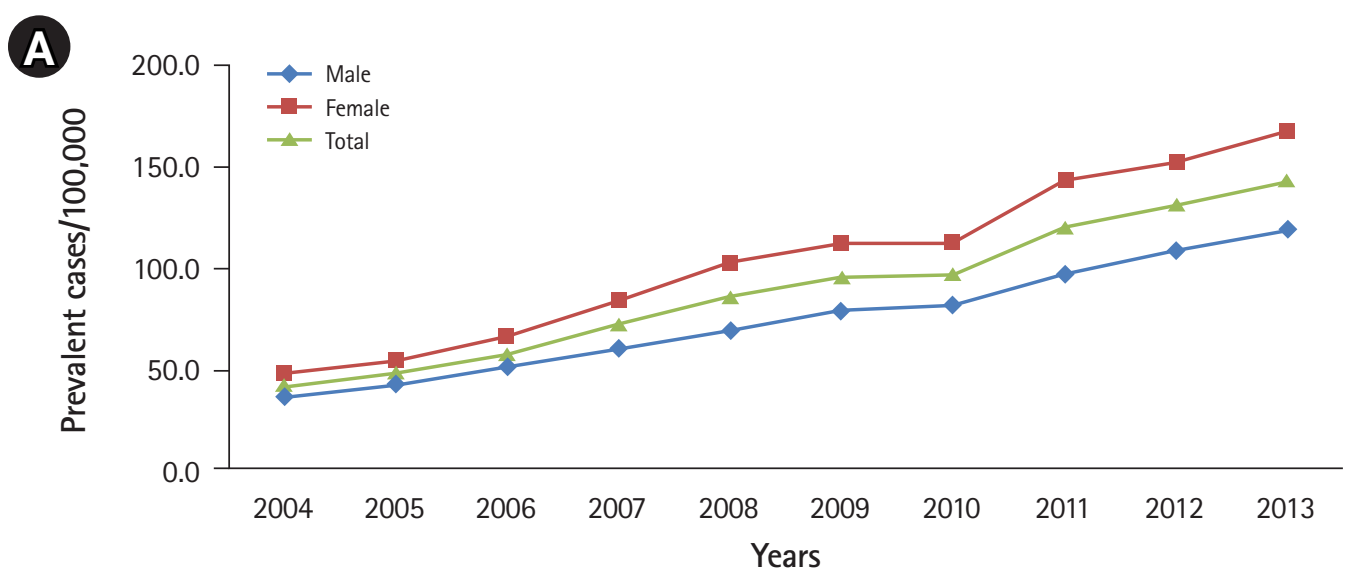

B

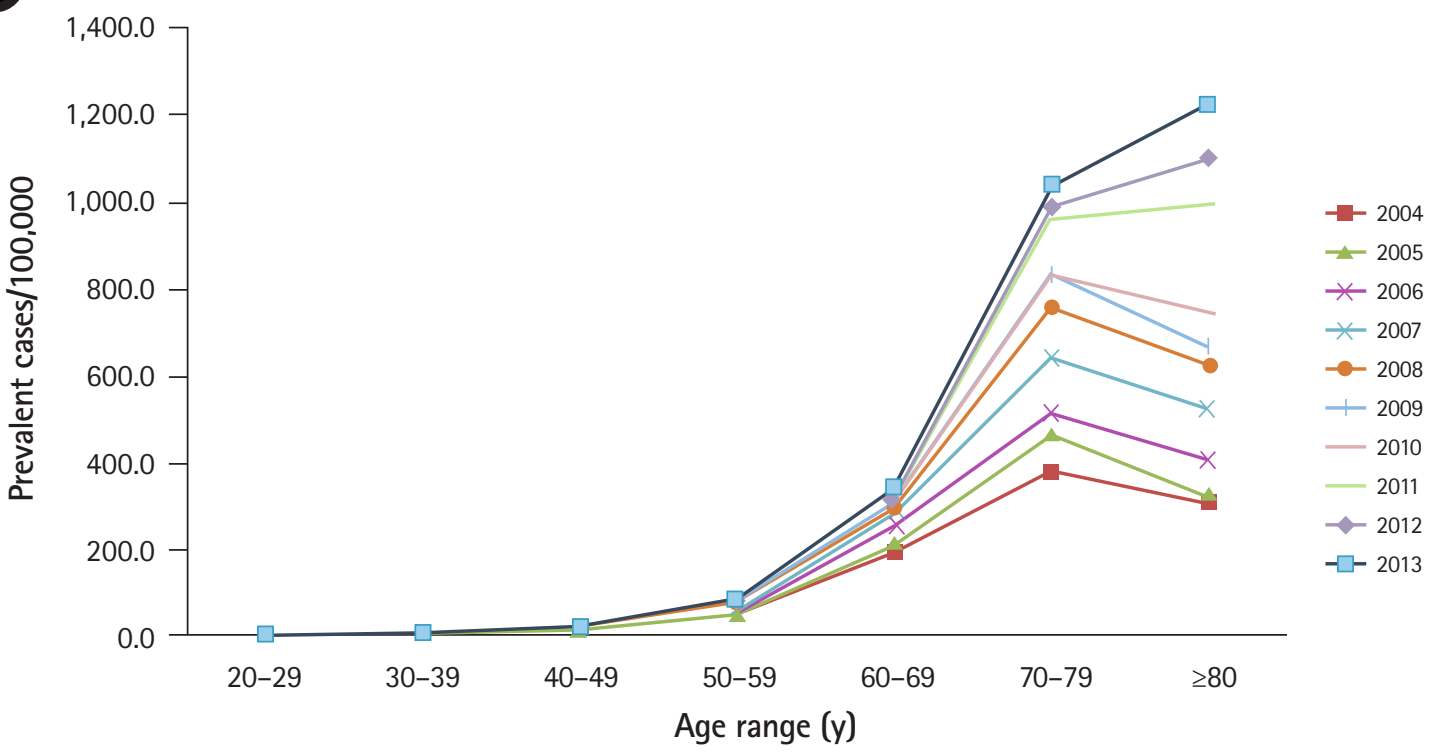

Figure 7. The trends in the prevalence of Parkinson's disease according to (A) sex and (B) age (2004-2013). Adapted from Lee JE, et al. J Korean Neurol Assoc 2017;35:191-198, according to the Creative Commons license [10].

\section{4. 노인 신경계 질환에 전문화된 진료 체계와 연구의 필요성} 고령 사회에서 필수적으로 뒤 따라야 할 것은 노인 건강 증진과 노화에 따른 질병을 관리하기 위한 포괄적이고 전문화된 보건의 료 시스템이 필요하다. 이러한 도전적 과제에 적절히 준비하지 못 한 다면 심각한 국가적 부담을 야기할 수밖에 없다. 특히 노인의 료비 증가를 해결하는 것이 과제인데 건강보험 심사결정기준으로 2008년 1월부터 2012년 12월까지 5개년 자료를 연간기준으로 인구의 고령화에 따른 노인 환자 증가는 치매, 뇌졸중, 파킨슨병 을 포함한 기타 퇴행성 질환같은 노인성질환의 영향이 컸다. 따라 서 5 개년 간 연평균 진료비 증가율이 전체 상병진료비 증가율인 $9.6 \%$ 에 비하여 노인성질환에서는 $22.8 \%$ 이 증가하여 월등히 높 은 결과를 보였다[13]. 또한 최근에 발표된 2020년 건강보험통계 연보에 따르면 $15.7 \%$ 고령인구가 전체 의료비의 $43.4 \%$ 인 37 조
6천억 원을 차지하고 지속적으로 증가하는 추세를 보이고 있으며 (Figure 9), 만성 신경계 질환으로 인한 비용이 큰 비중을 차지하 고 있기 때문에 신경계 질환을 가진 노인들에 대한 효율적이고 전 문화된 진료 체계 구축이 더욱 필요한 시점이다. 특히 노화에 따 른 신체 기능 저하를 평가를 포함한 포괄적인 다학제 진료 체계를 마련하여야 하며, 개인에 따라 다른 신체적, 심리적, 사회환경적 요소를 고려하고 환자와 가족의 참여 및 소통을 통한 개별 환자중 심 진료(person-centered care)가 중요하다[14].

고령인구의 증가와 함께 신경계 질환을 가진 초고령 노인 환자 가 늘고 있음에도 75 세 이상 초고령 노인 환자에 대한 임상연구 자료가 많지 않다. 따라서 진료 현장에서 환자와 그 가족들의 궁 금증과 걱정을 해소하는 데 항시 부족함을 느끼고 있는 것이 현실 이다. 이는 대부분의 임상연구, 특히 약물치료 연구에서 연구대상 


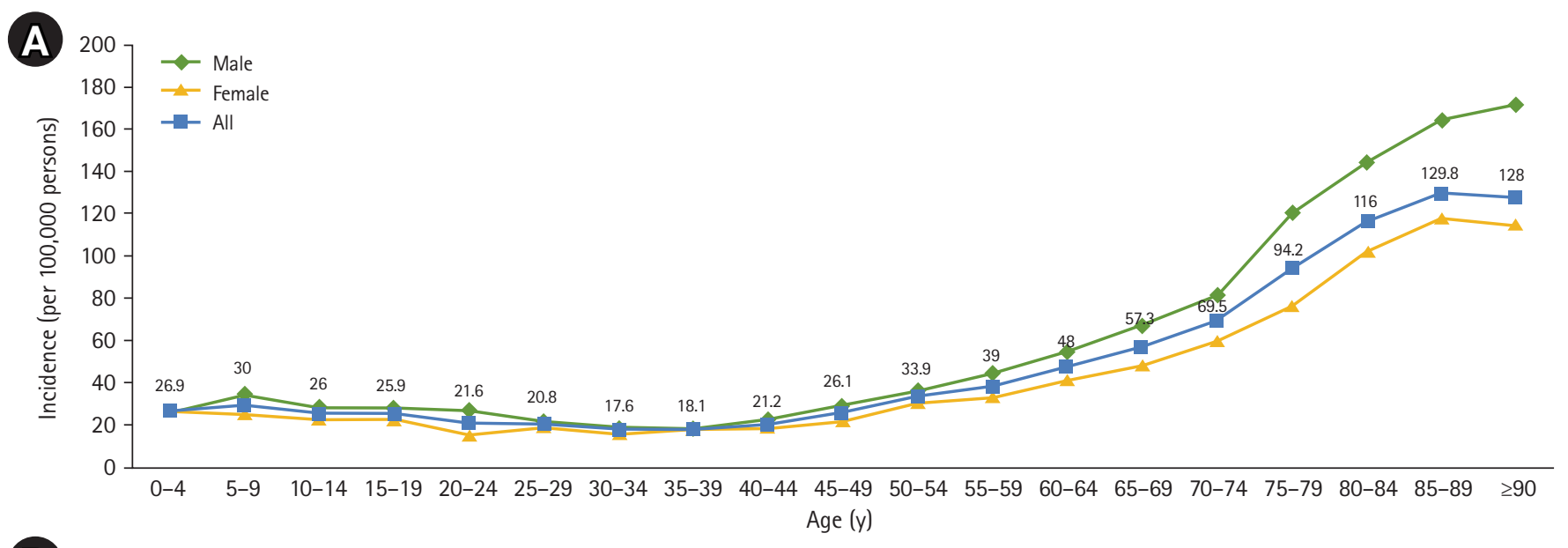

B)

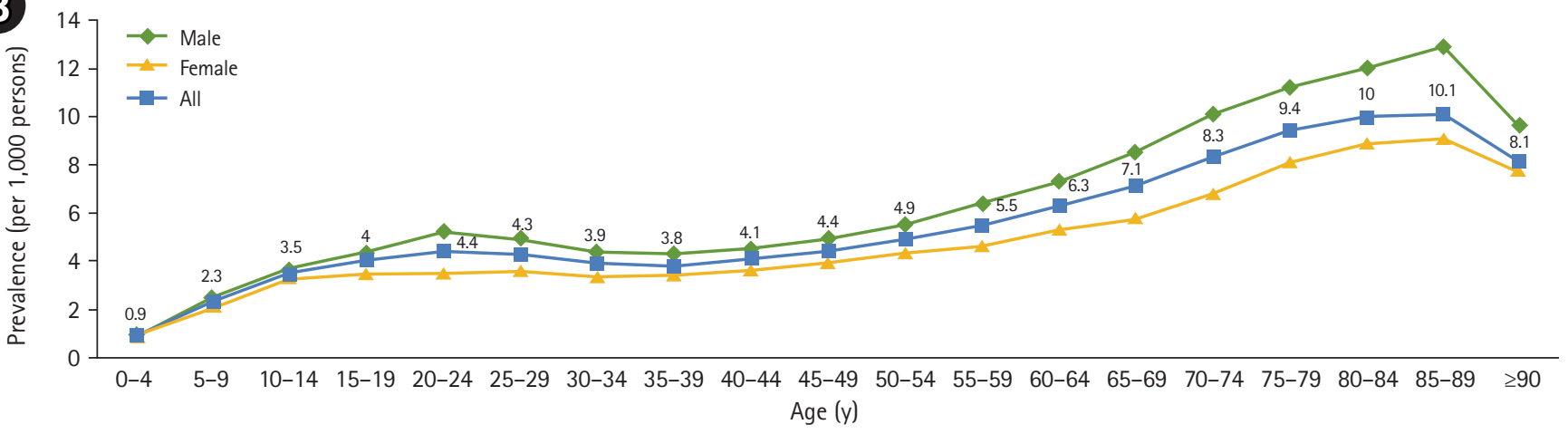

Figure 8. The trends of (A) indence and (B) prevalence of epilepsy by age (2017). Adapted from Jeon JY, et al. J Clin Neurol 2021;17:393399, according to the Creative Commons license [11].

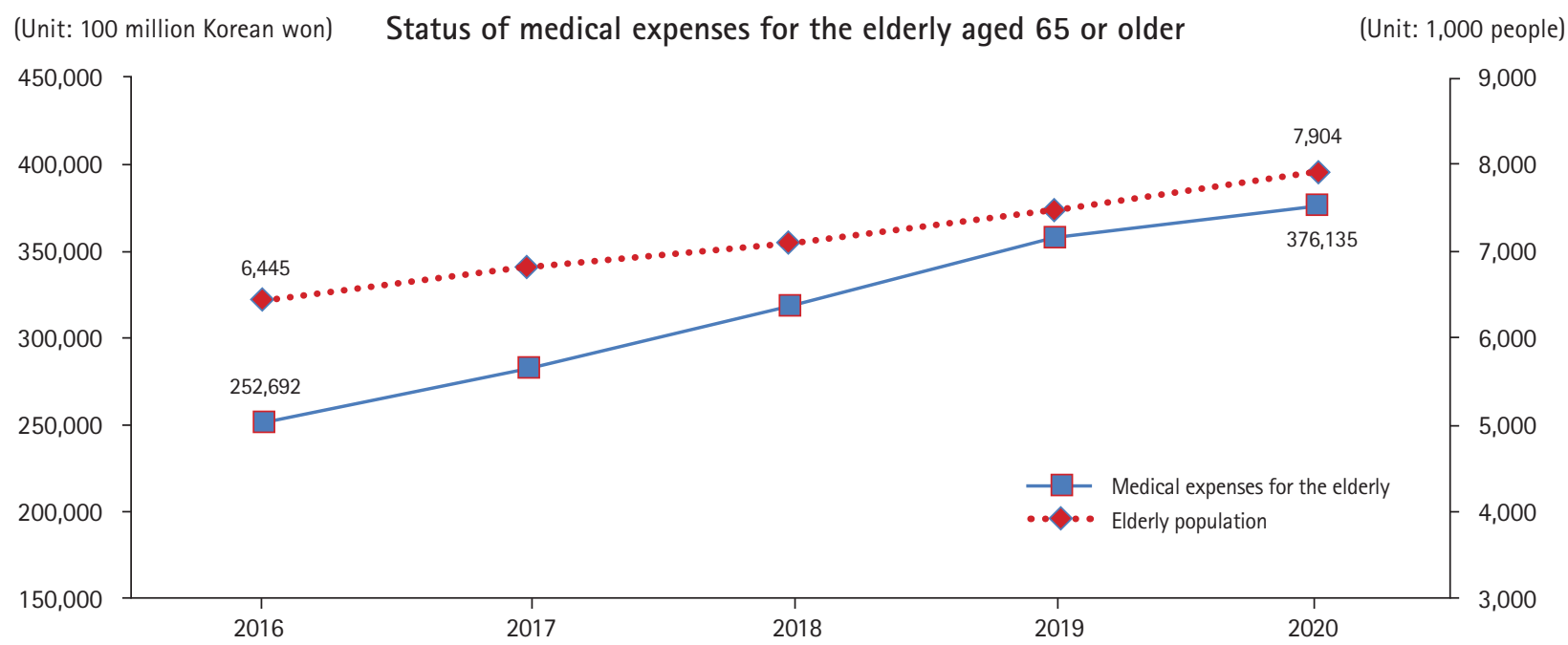

Figure 9. Status of medical experses for the elderly aged 65 or older. Source: 2020 National health insurance statistical year book (https:// www.hira.or.kr/bbsDummy.do?pgmid=HIRAA020045020000\&brdScnBItNo=4\&brdBItNo=2313\#none).

으로 초고령 노인이 여러 가지 이유로 제외되고 있기 때문이다 [15,16]. 우선 초고령 노인은 젊은 사람보다 여러 동반질환이 있 는 경우가 많아서 연구과정 중에 예기치 못한 변수가 있을 수 있
다. 다음으로 초고령 노인들은 다약제 복용(polypharmacy) 가능 성이 많고, 약물상호작용의 문제가 있을 수 있다. 또한 노화에 따 른 생물학적 변화와 체성분 변화에 따른 약동학(pharmacokinet- 
ics)과 약력학(pharmadynamics)이 달라지므로 부작용의 강도와 발생률이 높을 위험성이 있다. 마지막으로 초고령 노인에서 적극 적 약물치료나 시술이 의미 없는 것이라는 잘못된 인식이 있을 수 있고, 이러한 생각은 임상연구의 중요성에 대한 인식부족과 함께 연구 참여도를 떨어트리게 된다. 그러나 이러한 연구의 어려움을 고려하여도 초고령 인구가 지속적으로 증가하고 있는 상황에서 향후 진행할 모든 임상연구에서 고령인구를 증가를 반영하도록 보장하는 체계적 노력이 지속되어야 한다.

\section{결론}

노인에서 발생한 급성 및 만성 신경계 질환의 예방과 정확한 진 단, 적절한 치료를 위해서는 신경과학의 전문지식뿐 아니라 노화 와 노인의료에 대한 포괄적인 학문적 이해가 필수적이다. 10 년 내 에 우리나라는 세계에서 가장 긴 기대수명을 가진 장수국가가 될 것으로 예측하고 있으며, 치매, 뇌졸중, 파킨슨병을 포함한 신경 계 질환의 발생이 늘고 환자가 지속적으로 많아지고 있다. 이에 따라서 질병의 예방과 치료 영역에서 신경과 전문의 역할이 확대 되고 있으며, 치매안심센터 및 치매안심병원, 커뮤니티 케어 같은 공공의료 부분에서 국가적 요구도가 높아지고 있다. 이러한 역할 을 원활히 수행하기 위하여 선행되어야 할 것은 첫째, 전공의 수 련교육 프로그램에 기초적인 노인의학 및 노인신경학에 대한 체 계적 커리큘럼을 마련하고 제공하여야 한다. 이를 통해 신경과 의 사의 노인의료 전문가로서 역량을 높여야 한다. 둘째, 노인 신경 계 질환의 예방, 진단 그리고 치료에 대한 포괄적이고 체계적인 임상 데이터 축적과 연구에 관심과 노력이 필요하다. 이를 통하여 신경계 질환을 가진 노인 환자에 대한 최적의 진료를 위해 충분한 의학적 근거를 마련할 수 있게 될 것이다. 셋째, 신경계 질환을 가 진 노인 환자를 효과적이고 효율적으로 돌보기 위해서는 의사들, 간호사를 포함한 약사, 영양사 같은 훈련된 다학제 전문가들이 팀 으로 활동하는 포괄적 접근이 필요하다. 따라서 모든 관련 학회들 은 이러한 선행문제를 해결하고 노인신경의학에 대한 연구와 발 전을 위하여 더욱 매진해야 한다.

\section{Notes}

\section{Conflicts of Interest}

The author has no potential conflicts of interest to disclose.

\section{Funding}

None.

\section{ORCID}

Seung-Han Suk, https://orcid.org/0000-0002-8732-5021

\section{References}

1. Kontis V, Bennett JE, Mathers CD, Li G, Foreman K, Ezzati M. Future life expectancy in 35 industrialised countries: projections with a Bayesian model ensemble. Lancet 2017;389: 1323-1335.

2. Bartels SJ, Naslund JA. The underside of the silver tsunami: older adults and mental health care. N Engl J Med 2013;368: 493-496.

3. GBD 2016 Neurology Collaborators. Global, regional, and national burden of neurological disorders, 1990-2016: a systematic analysis for the Global Burden of Disease Study 2016. Lancet Neurol 2019;18:459-480.

4. Wikipedia contributors. Geriatric neurology [Internet]. Wikipedia, The Free Encyclopedia; 2021 Sep 15 [cited 2021 Dec 11]. Available from: https://en.wikipedia.org/w/index.php?title $=$ Geriatric_neurology\&oldid $=1044561270$.

5. Statistics Korea. 2020 Statistics Korea Life Table [Internet]. Seoul: Statistics Korea; 2020 [cited 2021 Dec 11]. Available from: https://www.kostat.go.kr/portal/korea/kor_nw/1/6/ 9/index.board. Korean.

6. National Health Insurance Service Ilsanhospital. A Study on the Improvement of Medical System Delivered to Longterm Care after Diagnosis of Degenerative Diseases Using Big Data from the National Health Insurance. Goyang: National Health Insurance Service Ilsanhospital; 2021.

7. Licher S, Darweesh SKL, Wolters FJ, Fani L, Heshmatollah A, Mutlu U, et al. Lifetime risk of common neurological diseases in the elderly population. J Neurol Neurosurg Psychiatry 2019;90:148-156.

8. World Health Organization (WHO). Global strategy and action plan on ageing and health [Internet]. Geneva: WHO; 2017 [cited 2021 Dec 11]. Available from: https://www.who. int/publications/i/item/9789241513500.

9. Kowalska M, Owecki M, Prendecki M, Wize K, Nowakowska J, Kozubski W, et al. Aging and neurological diseases. In: Dorszewska J, Kozubski W, eds. Senescence: physiology or pathology [Internet]. London: IntechOpen; 2017 [cited 2021 Dec 11]. Available from: https://doi.org/10.5772/intechopen. 69499.

10. Lee JE, Choi JK, Lim HS, Kim JH, Cho JH, Kim GS, et al. The prevalence and incidence of Parkinson's disease in South Korea: a 10-year nationwide population: based study. J Korean Neurol Assoc 2017;35:191-198. 
11. Jeon JY, Lee H, Shin JY, Moon HJ, Lee SY, Kim JM, et al. Increasing trends in the incidence and prevalence of epilepsy in Korea. J Clin Neurol 2021;17:393-399.

12. Bejot Y, Yaffe K. Ageing population: a neurological challenge. Neuroepidemiology 2019;52:76-77.

13. Shin HC. The trend of medical expenses for each disease over the past 5-years. Health Insur Rev Assess Serv 2014;8:61-74.

14. Jacobs AH, Emmert K, Baron R, Bartsch T, Bauer J, Becker C, et al. Neurogeriatrics-a vision for improved care and research for geriatric patients with predominating neurological disabilities. Z Gerontol Geriatr 2020;53:340-346.

15. Neurology in the elderly: more trials urgently needed. Lancet Neurol 2009;8:969.

16. Lindley RI. Stroke prevention in the very elderly. Stroke 2018;49:796-802. 